\title{
The Ethnocentric Steer \\ Perceptions and obsessions in the Introduction of European Livestock Science into Brazilian Tropical Cattle Ranching, c. $1880-1950$
}

\author{
Robert W. Wilcox*
}

Uma parte importante da Revolução Agrícola Europeia dos séculos 18 e 19 era a expansão da criação animal moderna. Imitando os acontecimentos na agricultura, criadores adotaram uma variedade de inovações técnicas. Criação seletiva, controle de doenças, gestão de pastos, etc. transformaram radicalmente um setor previamente inconsistente. Exportada rapidamente ao resto do mundo, a nova ciência animal chegou a definir o objetivo da criação nas regiões que chegariam a ser as mais importantes para gado bovino nas Américas, nos finais do século 19 inclusive no Brasil. Mas as novas técnicas se implementaram somente quando foram olhadas como úteis e acessíveis economicamente. Isso foi evidente em Mato Grosso especialmente, onde a pecuária teve uma longa história mas respondeu às exigências econômicas externas com uma mistura aparentemente contraditória de tradicionalismo lerdo e experimentalismo inovador. O resultado foi um debate entre os "modernizadores" que difamavam o estado da
"We know little about improvement of beef cattle in the tropics. It is still experimental." Otavio Domingues \& Jorge de Abreu, $1949^{1}$

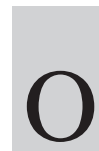
ne important aspect of the socalled European Agricultural Revolution of the eighteenth and nineteenth centuries was the development of modern animal husbandry. Following the pattern of the times, livestock raisers adopted a wide variety of technical elements that had seldom been considered before. Selective breeding, disease detection and control, pasture management, provision of dietary supplements, and access to a variety of resources to aid in the

\footnotetext{
* Northern Kentucky University - wilcox@nku.edu

${ }^{1}$ DOMINGUES, Otavio, ABREU, Jorge de. Viagem de estudos à Nhecolandia. Pub. N. 3. Rio de Janeiro: Instituto de Zootecnia, Dez. 1949, p. 3.
} 
indústria "retrógrada" local e os com experiência num setor que era isolado geograficamente e que gerava pouco lucro fora dos mercados locais.

Palavras-chave: Mato Grosso, pecuária, modernização.

An important part of the European Agricultural Revolution of the eighteenth and nineteenth centuries was the expansion of modern animal husbandry. Following on developments in crop agriculture, livestock farmers adopted a wide variety of technical innovations. Selective breeding, disease control, pasture management, etc. radically transformed a previously inconsistent sector. Rapidly exported to the rest of the world, the new animal science came to define the goal of livestock management in what soon became the premier global beef cattle producing regions of the Americas. By the mid to late-nineteenth century one of these was Brazil, though new techniques were only adopted as they were perceived to be useful and affordable. This was especially the case in Mato Grosso state, where ranching had a long history but responded to outside economic demands with a seemingly contradictory mixture of sluggish traditionalism and innovative experimentation. The result was a debate between "modernizers" who denigrated the "backward" state of the local industry and those with experience in a sector that was isolated geographically and generated limited income beyond local markets.

Keywords: Mato Grosso, cattle, modernization.

expansion of the business radically transformed livestock raising, most particularly in Britain. Soon exported to the rest of the world, this new animal science came to define the goal of livestock management in what would become the premier global beef cattle producing region of the Americas. The United States and Canada were the first New World laboratories, but impressive economic success in North America soon led to advocacy for South America, particularly by the late nineteenth century when demand for cheap and tasty beef had grown to produce a lucrative market in Europe, again especially Britain.

Yet while the widespread insertion of new technologies occurred in South America, in most cases techniques were only adopted as they were perceived to be useful and affordable. This was the case in various parts of the continent, but in particular in Mato Grosso state, a relatively remote corner of Brazil where ranching had a long history, but responded to outside economic demands with a seemingly contradictory mixture of what appeared to be sluggish traditionalism and innovative experimentation. In many ways, however, these responses were one and the same, for they reflected an understanding of available resources and the feasibility of adapting imported ideas and technology to local conditions. The result was a debate between those who denigrated the "backward" state of the local industry and sought to import European and North American innovations wholesale, and those with experience in an industry that was isolated geographically and generated limited income beyond local markets. While the entire cattle sector 
came under scrutiny, the controversy that ensued was most intensely directed to the breeding of cattle, the primary focus of this paper.

\section{"Tradition" Versus "Modernization"}

After the Civil War the United States simultaneously hosted rapid European immigration to northeastern cities and expanded rapidly westward to occupy lands at the expense of native peoples. This dual dynamic stimulated the beef cattle industry, particularly in Texas and the western plains, eventually extending north into the Canadian prairies. The steer of availability at the time was the famous Texas Longhorn, which was originally trailed from Texas to Kansas and then railed to Chicago for slaughter. Initially, western ranching was mostly open range, which suited the hardy Longhorn well. However, it became clear early that these animals were too skittish and "rangy" to accommodate on the tightly compacted rail cars, not to mention the inconvenience of their long horns. Even more important was the access to land. As the frontier attracted not only ranching but small farming, competition for land ensued. Though sometimes overstated, the real or potential conflict stimulated measures that guaranteed the eventual demise of the Longhorn. The most important was enclosure ${ }^{2}$.

As fencing became a key to protecting property, especially with the invention of barbed wire in the 1870 s, more "refined" animals that could be relatively easily controlled, and with a higher meat-to-weight ratio were sought. Barbed wire permitted the expansion of fencing in the American West especially, where the paucity of wood had limited enclosure. Perimeter fencing allowed ranchers to claim their large properties while also concentrating their animals, as well as control the often devastating prairie wildfires that plagued ranching and farming over the course of early settlement. Attention was then paid to raising more marketable animals for the eastern market, a desire that became acute after the 1886-87 winter storms that decimated herds, leading to the widespread introduction of the Shorthorn breed ${ }^{3}$.

\footnotetext{
${ }^{2}$ CRONON, Willian. Nature's Metropolis: Chicago and the Great Wes. New York: W. W. Norton, 1991, p. 218-221.

${ }^{3}$ Idem, p. 221; STARRS, Paul F. Let the Cowboy Ride: Cattle Ranching in the American West. Baltimore: The Johns Hopkins University Press, 1998, p. 118.
} 
Shorthorn had been developed in England during the early years of the nineteenth century and became popular in North America by mid-century for its "beefy" qualities. Along with periodic importations, purebred animals imported to Ohio in the 1830s became the seed stock for purebred breeding programs throughout the American Midwest and southern Canada over the following decades, particularly post-Civil War. Herd books and stock associations were established and the quality of breeders came to be based on one of two perceptions. The first was known as the four-cross system and determined eligibility for purebred status if animals were "bred up" from local stock using imported, registered pedigree males. The second was the closed herd book system that granted pedigree status only to animals directly descended from imported, registered animals. These perceptions came to frame a minor debate among stock breeders in North America, one that eventually was decided in favor of the closed system. Yet, the four-cross system was more practical in "sizing up" the U.S. beef cattle stock as it transitioned from relatively small and scrawny Longhorn to the larger and beefier Shorthorn and other breeds that in part descended from it like Hereford ${ }^{4}$. In the end, both systems functioned simultaneously, though thanks to international market demand for beef preceding and following World War One, "sizing up" came to dominate the industry, an approach that was absorbed by ranchers and breeders in Latin America and fueled perceptions of animal quality.

\section{Latin American Modernizations}

With independence in the early decades of the nineteenth century, almost from the outset the concept of "tradition" versus "modernization" came to dominate the rhetoric of social and political development in Latin America. While largely framed in racialist terms, by the last decades of the century this came to be mirrored through calls for "agricultural improvement" in terms of the organization of ranches, including introduction of wire fencing, planting of pasture, and particularly the quality of cattle, promoted by animal importers and zoo scientists from around the region ${ }^{5}$.

\footnotetext{
${ }^{4}$ DERRY, Margaret E. Bred for Perfection: Shorthorn Cattle, Collies, and Arabian Horses Since 1800. Baltimore: The Johns Hopkins Press, 2004, p. 33-34, 45-47. Shorthorn cattle are also referred to as "Durham", reflecting their geographical origin in Durham, England.

${ }^{5}$ In the sociopolitical realm, this racialism is most clearly expressed in Domingo Sarmiento's diatribe against the Argentina caudillo Rosas and his followers in the 1840s entitled "Civilization and
} 
By the last decades of the nineteenth century rural property holders, sometimes aided by government, had established agricultural organizations and had introduced measures that facilitated their businesses. Argentina was in the forefront of these measures, the most important being the Argentine Rural Society established in 1866. A similar society was established in Uruguay some years later, and in 1898 in Rio Grande do Sul in southern Brazil. These organizations were based primarily in the cities, and in Uruguay dominated by foreign interests. However, by the early twentieth century ranchers' and breeders' societies were formed throughout the region, in some cases supported by government, and influenced by innovative organization in Uruguay some ranchers in Rio Grande do Sul contributed to the formation of a veterinary school in the $1880 \mathrm{~s}^{6}$.

These efforts were largely modeled on Argentine experience and technical ideas emanating from Europe and North America. Euro-American approaches to agriculture and ranching were especially promoted through agricultural and husbandry periodicals that began to be published in the early years of the twentieth century. Recommendations published by these journals included establishment of veterinary schools, methods for "modernization" of ranches such as construction of cattle chutes, tick treatment, wire fencing, selective breeding, and organization of regional and national exhibitions. All were adopted in the region, first in Argentina and Uruguay, and unlike in the United States (though not Canada) with some direct and indirect support from government. The process was much slower in Brazil, however, as witnessed by the fact that the first national cattle exhibition occurred in Rio de Janeiro in 1917, a full forty years after the Argentine Rural Society had organized the 1876 exhibition in Buenos Aires ${ }^{7}$.

On the ground, one of the most important introductions was planted pasture. Again, Argentina led the exotic pasture revolution. Alfalfa, introduced as early as the 1860s, became a savior for ranchers as it grew especially well on the Pampa and became an essential part of the socioeconomic structure of ranching and

Barbarism”. SARMIENTO, Domingo F. Life in the Argentine Republic in the Days of the Tyrants: Or, Civilization and Barbarism. New York: Hafner, n.d.

${ }^{6}$ BELL, Stephen. Campanha Gaúcha: A Brazilian Ranching System, 1850 -1920. Stanford, CA: Stanford University Press, 1998, p. 85-88.

${ }^{7}$ Idem, p. 90-96. For Canadian government support/regulation in Shorthorn breeding, see Derry, Bred for Perfection, Chapter Two. 
agriculture in that country for decades. In fact, demands in Europe for quality meat meant that alfalfa came to be seen by Argentines and Europeans alike as the key to such production. The same perception was then followed in Uruguay and Rio Grande do Sul, but due to less hospitable soil conditions most alfalfa had to be imported into both regions. This didn't stop criticism of ranchers for not growing it of course, but little was undertaken until after World War One due to lack of financial and other resources for planting, plus resistance from ranchers who had been relatively successful relying on native pastures for decades ${ }^{8}$.

Despite these introductions, successful or otherwise, the most immediate criterion for judging the future of ranching in the region had to do with cattle breed. Debate over the quality of beef cattle breeds spread across South America, especially as the European market expanded. In Argentina it tended to mirror some of the racialist arguments made at the time and earlier about the quality of native workers and the need to encourage immigration to "civilize" the country. Breeder animals from Britain or North America were seen as essential in "improving" local Creole herds for sale abroad, and while there was considerable economic rationale to the approach the discussion often became polemical as local cattle were seen as degenerate and in need of crossbreeding if the livestock sector was to prosper. This perception was reflected in Brazil as well.

"Traditional" ranching in Spanish and Portuguese America had relied on animals that had been imported from Iberia during the colonial period and had then adapted to regional conditions. These animals shared the same ancestors as the Texas Longhorn, but in Latin America were referred to as criollos (Creoles), though each region had its own names and slight variations. They were normally muscular, heavily-boned animals with short legs, long, curved horns, and powerful front quarters (including the head), suited to draft labor. As decades and centuries passed, cattle adapted to local conditions and developed characteristics unknown to their ancestors. Most noticeable were the enlargement of horns, necessary in an extensive ranching system for defense against predators like wildcats. As a result of this type of ranching, cattle became semi-feral, shied from humans, and were not indisposed to put up a fight at roundup time. These "American" animals became more suited to the tropics, developing wider hooves, thick skins, and strong constitutions that were adaptations

${ }^{8}$ BELL, Stephen. Op. cit., p. 128-132. 
to the local environment. Over the course of three to four hundred years the Creole had served the needs of the colonial and early national economies well. However, with the development of selective breeding in Europe and the United States, and an expanded market overseas for South American beef, criollos no longer sufficed. As in the U.S. with the Longhorn, the reasons were largely because these animals were smaller, harder to handle, and carried tougher flesh than that desired in an increasingly discriminating British market. The solution, of course, was to breed desired characteristics into these "degenerates",

Chile was perhaps the first destination of European Durham/Shorthorn breeders in the 1840s, though it was in Argentina that stock breeding took on a commercial character that enhanced the nation's exports significantly. Argentina was by far the most developed of Latin American cattle economies, therefore the first to adopt the modern scientific approaches promoted in Europe and North America. Yet none of this moved rapidly. Both in Argentina and Uruguay stock raising was important throughout the last half of the nineteenth century, although it only took on a serious international character after the end of the Paraguayan War (1864-70). Borrowing from the British and North American experience, rural associations were established in Argentina in 1866 and in Uruguay in 1871. In the 1870 s and 1880 s both made every effort to stimulate scientific breeding practices in order to satisfy the increasingly discerning market of Britain. The task was to "improve" largely criollo cattle after the several centuries of "degeneration" through "sizing up". Shorthorn dominated Argentine breeding efforts, and until well after World War One were the breed of choice to cross with the mestizos (mixed breeds of Shorthorn and Creole) on the Plata range. By the second decade of the twentieth century Hereford and Devon were seen as more suitable to Uruguayan pastures. Hereford were also brought from Uruguay to Rio Grande do Sul, though the modernization process here was much slower than in the Río de la $\mathrm{Plata}^{10}$.

\footnotetext{
${ }^{9}$ COTRIM, Eduardo. A Fazenda Moderna: Guia do Criador de Gado Bovino no Brasil. Brussels: Typ V. Verteneuil et L. Desmet, 1913, p. 1913; CAVALCANTI, Manuel Paulino. Raças de carne. Rio de Janeiro: Ministério da Agricultura, Industria e Commercio, 1928, p. 33-34.

${ }^{10}$ TUCKER, Richard P. Insatiable Appetite: The United States and the Degradation of the Tropical World. Berkeley: University of California Press, 2000, p. 302-303: SLATTA, Richard W. Cowboys of the Americas. New Haven, CT: Yale University Press, 1990, p. 17; BELL, Stephen. Op. cit., pp. $85,90,111,113-115$.
} 
Some of the first deliberate efforts in Brazil to import animals for breeding began in Rio Grande do Sul, which had a history of cattle ranching stretching back to colonial times. Though in Argentina and Uruguay some ranchers had begun experimentation in selective breeding by the 1850s, in Rio Grande do Sul only in the latter years of the nineteenth century and early part of the twentieth did local ranchers regularly follow that lead. While heavily influenced by their neighbors to the south, even here the experience of Argentina or southern Uruguay was not entirely applicable to sulriograndense ranchers' experience. Though several ranchers and veterinarians experimented with Shorthorn, for example, this breed was thought by animal scientists to be inappropriate to the dry climate and less nutritious grasses of southern Brazil. Instead, Devon or Polled Angus were preferred. Yet ranchers in Rio Grande do Sul were strongly influenced by experience in neighboring Uruguay, where Hereford predominated, followed by Shorthorn. The result was that by the 1920s the dominant breeds in Rio Grande do Sul herds were Hereford and Shorthorn. Typical of the time, success in other parts of the world, in this case the Río de la Plata, determined the selective breeding of Rio Grande do Sul, regardless of environmental conditions. This perspective would be overcome only several decades later, but continued to be reflected in perceptions of ranching in the remote interior state of Mato Grosso, though with an added twist ${ }^{11}$.

\section{The Case of Mato Grosso}

During the decades under study here the Mato Grosso cattle industry experienced significant economic expansion. This included the processing of beef jerky and beef bouillon and increased exports of live cattle and of cattle products to other regions of Brazil. Yet despite growth in human and animal populations, Mato Grosso ranching did not produce as did that of Argentina or even some other regions of Brazil, therefore receiving considerable criticism for being the cause of it own underdevelopment. Throughout much of the period, this so-called backwardness was a major concern of the region's presidents, and some of this was attributed to the lack of imagination of local residents. As early as 1872 in an analysis of the state of ranching and agriculture in Mato

${ }^{11}$ BELL, Stephen. Op. cit., p. 113-115. 
Grosso, President José Cardoso Junior complained there was virtually no development. Part of the blame fell on "lazy Matogrossenses", but mention was also made of a lack of manpower due to the recently-terminated Paraguayan War (1864-70), irregular transportation facilities, a lack of capital, and disease. The national government in Rio de Janeiro was called upon to accord greater attention to the area if it was ever to emerge from its "lethargy." Apparently this lament was heard on the coast, for in 1873 most cattle products were exempted from export taxes, while in 1874 a prize of 5 milréis (\$2.60 U.S.) per head was offered for the importation of purebred breeding bulls from Europe or Argenti$\mathrm{na}^{12}$. Yet little appears to have come of these efforts, for in 1887 President Ramos Ferreira lamented the "primitive" state of ranching:

Cattle are raised [according] to the law of nature, released onto the range [campos], subject to bad weather, entrusted to public honor; there is no stabling; forage is acquired on the range, no matter the season; [only] one or two ranchers have fencing, causing frequent rustling among neighbors; existing breeds, perhaps the same as those of colonial times, have not been improved through selective breeding. ${ }^{13}$

This observation was elaborated upon by João Severiano da Fonseca, who traveled through the area as part of the Brazilian commission demarcating the Brazilian-Bolivian border. Fonseca saw a profound lack of initiative among Mato Grosso ranchers, who were involved only in the buying and selling of their animals, otherwise allowing cattle to fend for themselves in a semi-feral state. He argued that most Brazilian ranchers were aware of measures to control their animals, provide water and salt, plant pasture, etc., yet in Mato Grosso such practices were either unknown or ignored, to the detriment of the industry's future ${ }^{14} \cdot{ }^{15}$

\footnotetext{
${ }^{12}$ Relatório apresentado à assembléa legislativa da província de Matto-Grosso, 4 de outubro de 1872 pelo Presidente, Tenente Coronel Dr. Francisco José Cardozo Junior. Rio de Janeiro: n.p., 1872, p. 86-87, 91; MOUTINHO, Joaquim Ferreira. Noticia sobre a província de Matto Grosso seguido d'um roteiro da viagem da sua capital à S. Paulo. Rio de Janeiro: Typ. de Henrique Shroeder, 1869, p. 31-35, CORRÊA FILHO, Virgilio. A propósito do boi pantaneiro. Rio de Janeiro: Pongetti, 1926, p. $39-40$.

13 “Industria Pastoril”. Relatório do vice-presidente Dr. José Joaquim Ramos Ferreira devia apresentar à Assembléa Legislativa Provincial de Matto Grosso 2a Legislatura de Setembro de 1887. Cuiabá: n.p., 1887, n. p.

${ }^{14}$ FONSECA, João Severiano da. Viagem ao Redor do Brasil: 1875-78, v. 1. Rio de Janeiro: Bib. do Exército Ed., 1986, p. 165-167.
} 
The same sentiment was expressed throughout the succeeding decades, and well into the twentieth century. But this wasn't confined only to Mato Grosso. Ranching throughout the country, particularly in the center-west, occasioned reprimand for its "rudimentary" character. In 1903, a study of ranching in Minas Gerais argued that the alleged problem was a combination of insufficient capital investment, technical skill and opportunities for training, and government interest. The author suggested a number of measures to improve the state's industry, including better and cheaper transportation, construction of local slaughterhouses (frigorificos) and jerky plants (charqueadas), and organization of marketing through cattle fairs ${ }^{16}$.

"Backward" ranching was still a concern in Brazil ten years later, when Eduardo Cotrim, the distinguished Brazilian veterinarian and agricultural expert in the São Paulo state government, reported that Brazilian ranching had hardly developed in recent years:

We do not have any method whatsoever. Up to today, our cattle have lived in complete abandonment. The industry does not exist because the system adopted as the most convenient is that of perfect barbarism [selvageria].

Cotrim believed that only with strict care of the cattle and stimulation of the industry through better pastures and the use of high quality breeder bulls, would ranching emerge from its lethargy ${ }^{17}$.

Meanwhile, constant laments became almost routine over the years in Mato Grosso. In 1907, distinguished Mato Grosso historian and modernizer Virgílio Alves Corrêa, listed the reasons why ranching did not develop in the state. He mentioned the ease in which ranching could be engaged and the usual government inertia in recognizing the importance of the industry to the region and to one's own income. But he also mentioned high taxes and freight rates, which discouraged imports of fencing wire and breeder animals. He did not spare the form of ranching, however, and especially condemned the practice of communal cattle raising and field burning,

\footnotetext{
${ }^{16}$ FORTES, Carlos Pereira de Sá. Industria pastoril; relatório apresentado à commissão fundamental do Congresso Agrícola, Commercial e Industrial de Minas. Belo Horizonte: n. p., 1903, p. 11-12, 7281.

${ }^{17}$ COTRIM, Eduardo. Op. cit., p. 145.
} 
which exhausted pastures and added to care costs and losses of animals through lack of control. Drawing on the model of the Río de la Plata, Corrêa urged the federal government to support local ranching with subsidies, tax exemptions and free training ${ }^{18}$.

\section{Experimental Farms and Model Ranches}

Official action was seldom forthcoming since government resources were scarce and politicians were further limited by competing political demands. The situation began a slow transformation, however, with the boom of the First World War, when the value of Mato Grosso cattle increased significantly and the state was inextricably drawn into the national and international economic system. This process actually had begun some years before the war, as outside investors took interest in the onceignored region, and recommendations were made for stimulation of the regional cattle industry. In 1912, President Costa Marques suggested control of the sale of breeder-age cows and heifers, the subdivision of large ranches, introduction of fencing on a wider scale, improvement of transportation facilities, and the development of an effective medicine to combat diseases like surra. He suggested that the state offer assistance in finding a cure, and that it establish an experimental farm (campo de demonstração), to improve cattle breeds. These suggestions, though not new, fell on more responsive ears with the wartime demand for cattle products, and eventually some measures were taken to support the industry ${ }^{19}$.

A state agricultural school and experimental farm were established near Cuiabá in 1912-13, in emulation of similar initiatives in São Paulo beginning in 1895. Though not a major cattle producer, São Paulo was in the forefront of much agricultural innovation in Brazil, and had created not only schools and experimental farms, but also zoo-technical posts for the care and study of animals, and a state-wide

\footnotetext{
${ }^{18}$ CORRÊA, Virgilio Alves. "Aos Fazendeiros”. Revista da Sociedade Matto-Grossense de Agricultura Cuiabá, n. 1, may 1907, p. 13-20, 28-31.

${ }^{19}$ Mensagem pelo Dr. Joaquim A. da Costa Marques, Presidente do Estado à Assembléa Legislativa, 13 de maio de 1913. Cuiabá: Typ. Official, 1913, p. 33-34.
} 
genealogical herd or stud book in $1908^{20}$. Meanwhile, the war stimulated the creation of a feira de gado (cattle market or fair) in 1919 at Três Lagoas, modeled on feiras established during the colonial era and especially in Minas Gerais at the end of the nineteenth century. These measures were intended to encourage the application of modern ranching methods, as practiced in Argentina and the United States, and also to aid in the marketing of Mato Grosso cattle to the São Paulo slaughterhouses. In 1918, the federal government also proposed to set up a fazenda modelo (model ranch) in Campo Grande on land provided by the state, but the state government in Cuiabá delayed acquiring the site. In his 1926 report, President Mario Corrêa da Costa reported that the model ranch was not yet functioning, even though the state had bought land and donated it to the Ministry of Agriculture, and a director had been appointed in 1924. Nevertheless, the ranch was still idle in $1929^{21}$.

By the time of the Getúlio Vargas-led revolution of the following year, the Campo Grande ranch had only planted a few hectares of pasture and no buildings

\footnotetext{
${ }^{20}$ Herd books were established in Argentina and Uruguay in the 1880s, while São Paulo was not the first to establish a herd or stud registry in Brazil. This was done in Rio Grande do Sul in 1906, and the idea caught on. By 1911 a genealogical registry had been set up in Uberaba, Minas Gerais, a herd book for the native caracu cattle breed in 1916 in São Paulo, and another for zebu in 1919, again in Uberaba.. Mato Grosso, however, did not participate in these innovations during the period. See BELL, Stephen. Op. cit., p. 111-112 and LOPES, Maria Antonio Borges, REZENDE, Eliane M. Marquez de. ABCZ, 50 Anos de História e Estórias. Uberaba, Minas Gerais: Associação Brasileira de Criadores de Zebu, 1984, p. 44-45.

${ }^{21}$ Mensagem... 1913, op. cit., p. 74; SECRETARIA DE ESTADO DOS NEGOCIOS DA AGRICULTURA, COMMERCIO E OBRAS PÚBLICAS. Almanach para o anno de 1917. São Paulo: Secretaria de Estado, 1917, pp.40, 56, 113, 122; ROCHA, Geraldo Leme da, PIETROSANTO, Ademir Giacomo. "O Instituto de Zootecnia e a agropecuária Brasileira”. Instituto de Zootecnia. Boletim Técnico. Nova Odessa, SP, n. 20, 1986, p. 3-16; A FEIRA DE GADO DE TRES LAGOAS. Creação e installação. São Paulo: n. p., 1922, p. 7-10, 23; COSTA, Pedro Celestino Corrêa da. "Crise da pecuaria. Revista da Sociedade Rural do Brasil. São Paulo, n.27, set. 1922, p. 523; Mensagem dirigida pelo Dr. Caetano Manoel de Faria e Albuquerque, Presidente de Matto Grosso, à Assembléa Legislativa, 15 de maio de 1916. Cuiabá: Typ. Official, 1916, p. 23-25; Mensagem à Assembléa Legislativa, 7 de setembro de 1920 por D. Francisco de Aquino Corrêa, Bispo de Prusiade, Presidente do Estado. Cuiabá: Typ. Official, 1920, p. 85-87, 96-104; Mensagem do Presidente de Mato Grosso, D. Francisco de Aquino Corrêa, 7 de setembro de 1919. Cuiabá: Typ. Official, 1919, p. 1617; Mensagem do Estado de Mato Grosso. Cuiabá: Typ. Official, 1927, p. 155; Letter from the director of the Fazenda Modelo de Criação, A, Teixeira Vianna, to the presidente of Mato Grosso, Campo Grande, 2 August 1925. Documentos avulses, lata 1925-B, Arquivo Publico do Estado de Mato Grosso [hereafter APMT]; Mensagem apresentada à Assembléa Legislativa pelo Presidente de Mato Grosso, Dr. Annibal Toledo, 13 de maio de 1930. Cuiabá: Typ. Official, 1930, p. 24.
} 
had yet been constructed. It was reported that the 1930 Revolution halted even this minimal activity, not surprising since the dictatorship that followed replaced most public officials. But the Vargas regime paid more attention to establishing Brazil's hold on its remote regions than had previous governments, and by 1936 the ranch was in operation, engaging in breeding experiments under the direction of the Ministry of Agriculture. Eventually, the site became the national center for the study of beef cattle, under the auspices of the federal Empresa Brasileira de Pesquisa Agropecuária (EMBRAPA) 22 .

Yet another factor that contributed to outside observers' criticism of local cattle ranching was the number of cattle grazing the land. Although herd populations were often difficult to ascertain with any accuracy, many observers noted the vast expanses set aside for relatively small numbers of animals. In the 1890s, Rodolpho Endlich's study of the region estimated that local conditions demanded three hectares per head, compared with 2.3 to 3 hectares in neighboring Paraguay and 1.8 hectares in Argentina. This meant that a ranch of 10,000 hectares should carry no more than 3,300 head of cattle. In Mato Grosso, however, it appears such numbers were not common. Endlich himself reported that a ranch of over 850,000 hectares hosted some 80,000 animals, a proportion of over 10 hectares per head. Later observers noted similar land-to-animal ratios, including a ranch in 1907 extending over 385,000 hectares and pasturing roughly 30,000 head (almost 13 hectares per head). Miguel Lisboa, who participated in the initial railroad survey across southern Mato Grosso, noted that circumstances differed within Mato Grosso, depending on local environmental and geographic conditions. In the Pantanal flood plain he believed the land could support one head per 2.2 hectares, while in the higher elevations (cerrado or planalto), where the soil was less fertile and rainfall less frequent, this ratio increased to one head per 4.5 to 6 hectares. In the more fertile Vacaria (campo limpo) in the Paraná River watershed, conditions were more favorable: 3.6 to 4.5 hectares to an animal ${ }^{23}$.

\footnotetext{
${ }^{22}$ ANDRADE, Arlindo de. Erros da federação. São Paulo: n. p., 1934, p. 77; ANDRADE, Dolor F. Mato Grosso e a sua pecuária. São Paulo: Universidade de São Paulo, 1936, p. 8.

${ }^{23}$ ENDLICH, Rodolpho. "A criação do gado vaccum nas partes interiores da América do Sul". Boletim da Agricultura. São Paulo, n. 4, 1903 \#2, p. 82-84; n. 4, 1903 \# 3, p. 128-129; LISBOA, Miguel Arrojado Ribeiro. Oeste de S. Paulo, Sul de Mato-Grosso. Geologia Mineral, Clima, Vegeta-
} 
The apparent contradictions between Endlich's observations and those of Lisboa reflect the uncertain application of the science of animal husbandry to tropical or semi-tropical regions like Mato Grosso. As time passed and more studies were made of the region and of ranching throughout Brazil, further recommendations were made. In the 1920s it was estimated that depending on the region, Mato Grosso natural pastures could support one head to between 2 and 5.5 hectares. By comparison, in 1916 Argentina already was operating on a ratio of one steer per hectare. Little had changed by the mid-1930s, when pasture capacities were observed to be one animal to between 3.6 and 4.5 hectares in good pasture conditions, and 7 and 12 hectares per head on poor pastures. As an example of general perceptions, during the 1930s the Vargas government calculated territorial tax based on 6 hectares per head. In the early 1950s it was estimated that the planalto region could support one head per 2.4 to 3 hectares on natural grasses, but up to 2 head per hectare on planted pasture. In the Pantanal, this ratio was put at between 2.9 and 3.3 hectares per animal on natural pasture, while the Vacaria was said to support 1.3 head per hectare on its natural pasture ${ }^{24}$. This led to increased attention to the introduction of exotic pastures to expand the potential number of animals that could be raised in the state.

\section{Pasture Introduction}

One of the issues that was key to understanding the relationships government and ranchers had with science was the question of pasture. Attempts were made

ção, Solo Agrícola, Industria Pastoril. Rio de Janeiro: Typ. do “Jornal do Commercio”, 1909, p. 141150. Cattle counts on other ranches revealed that these ideal conditions were seldom even achieved. For example, the various ranches the yerba mate tea giant Mate Larangeira owned near the Paraguayan borded provided between 5 and 12 hectares per animal. DECOUD, Arsenio López. Album Grafico de la Republica del Paraguay. Buenos Aires: n. p., 1911, p. XLV-XLVI.

${ }^{24}$ NASH, Roy. The Conquest of Brazil. New York: AMS Press, 192?, p. 255; "Primeiro Congresso de Pecuaria”. Correio Paulistano. São Paulo, Sept. 19, 1916, p. 2; ANDRADE, Dolor F. Op. cit., p. 11; MONSERRAT, Econ J., GONÇALVES, Carlos A. Observações sôbre a pecuária no Brasil Central: Relatório de viagem apresentado ao Ilmo. Sr. Dr. Manoel Corrêa Soares D.D. Presidente do Instituto Sul Rio Grandense de Carnes, em 8 de agôsto de 1953. Porto Alegre: n. p., 1954, p. 53; VIEIRA, Mauricio Coelho. "A pecuária”, in BRASIL. CONSELHO NACIONAL DE GEOGRAFIA. BIBLIOTECA GEOGRÁFICA BRASILEIRA. Geografia do Brasil: Grande Região CentroOeste. V. II, pub. N. 16. Rio de Janeiro: IBGE, 1960, p. 196-199. 
by some ranchers, particularly foreign consortia established before and during the First World War, to introduce exotic grasses to Mato Grosso. The major stimulus came from a U.S.-registered company called Brazil Land, Cattle and Products Company, owned by the Percival Farquhar syndicate, which was one of the first to install fencing throughout the ranch, import breeder bulls and introduce exotic grasses on its ranches in the cerrado and campo limpo. But the perceived urgent need to emulate the successes of Argentina led to the almost exclusive obsession to introduce exotic forage, as pasture ${ }^{25}$.

The example set by Brazil Land was followed by all other foreign operations and even some Brazilian ranchers with sufficient capital for the investment. Grasses like jaraguá (Hyparrenhia rufa) and gordura (Melinis multiflora), plus rhodes grass, sorghum grass and even alfalfa, were planted by Brazil Land. However, very soon it became clear that alfalfa did not do well in Mato Grosso. The most successful were the African-origin jaraguá and gordura, which had acclimatized to Brazil over the course of the colonial period, and these were the principal species recommended, not only by the company, but also by agronomists in São Paulo and Rio. Planting followed the same pattern in the neighboring state of São Paulo, where fattening pastures near the slaughterhouses of Barretos, Osasco and elsewhere were sown with jaraguá and colonião (Panicum maximum) ${ }^{26}$.

The need for planted pasture in Mato Grosso, however, was limited. There were extensive tracts of natural pasture throughout the south of the state, and the expense of stringing fences and planting and maintaining pasture were simply beyond the means of most ranchers. Only with gradually increased wealth and diminishing access to native grasses did ranchers turn to planting. For the most part, this did not occur on a wide scale until after the Second World War, and only became common in the state (except for the Pantanal) since the $1970 \mathrm{~s}^{27}$.

${ }^{25}$ ESTADO DE MATTO GROSSO. O Município de Campo Grande, Estado de Matto-Grosso. Pub. Official: n. p., 1919, p. 65-77; TRAVASSOS, J. Carlos. Industria pastoril. Fascículo n. 2. Rio de Janeiro: Sociedade Nacional de Agricultura, 1898, p. 29-30.

${ }^{26}$ ESTADO DE MATTO GROSSO. Op. cit., p. 57, 65-77; BRASIL. Estudo dos factores...Campo Grande, p. 13-14, 32; CAMPO GRANDE. MATTO GROSSO. O município de Campo Grande em 1922: pub. da intendência municipal. São Paulo: Cia. Melhoramentos, 1923, p. 48-49; COTRIM, Eduardo. Op. cit., p. 90-109; MONSERRAT, Econ J., GONÇALVES, Carlos A. Op. cit., p. 18-19. ${ }^{27}$ VIEIRA, Mauricio Coelho. Op. cit., p. 191-193, 195-197; PEBAYLE, Raymond, KOECHLIN, Jean. "Les fronts pionniers du Mato Grosso méridional: approche géographique et écologique" in 
Under these circumstances, questions were raised over how the region could participate in wider production when the quantity of animals on the land was so minimal. Inevitably, much of the discussion turned to the "quality" of the animals themselves. While other issues, such as natality and mortality rates, access to nutritious grasses, disease, etc. played important roles, many observers saw only scrawny, semi-feral animals and concluded that the best solution was to breed larger and fleshier animals, the apparent key to success in Europe, North America, and the Río de la Plata.

\section{Cattle Breeds of Mato Grosso}

The issue of breed type became a national controversy in the early decades of the twentieth century as researchers and veterinarians entered the debate over the suitability of certain cattle to the Brazilian environment, particularly Hereford and Durham from the United States, zebu from the Indian subcontinent, and a "Brazilian" breed called the caracu. Mato Grosso became a part of this debate early, and served as a laboratory for the efficacy of one over the other. The outcome was fundamental to establishing Mato Grosso's credentials as a major cattle raising region.

The breed of cattle entering Mato Grosso with the first neo-European settlers was that familiar to ranchers throughout the Americas, the criollo (crioulo in Portuguese). Yet over time a number of regional breeds developed. After the Paraguayan War the most common breeds were the pantaneiro or cuiabano in the Pantanal, and the chino and franqueiro in the planalto, although these were not mutually exclusive. Lucídio Rondon stated that the pantaneiro was the result of crossbreeding between caracu and franqueiro, although other evidence suggests that the animal descended from crosses between Brazilian, Paraguayan and correntino cattle from Argentina or Paraguay. It was small and agile, sported large, narrow horns, had a thick hide, and was adapted to regular flooding of its habitat. Its rate of survival under arduous conditions was remarkably high, with close to 20 percent annual herd growth, a characteristic that guaranteed increases

PEBAYLE, Raymond et alii. Le Bassin Moyen du Paraná Brésilien: L’Homme et son milieu. Bordeaux: Centre d’Etudes de Géographie Tropicale, CNRS, 1978, p. 149. 
with little effort on the part of the rancher. The conditions under which the pantaneiro were raised were hardly conducive to weight gain, however. The animal's slow maturation, light weight, and allegedly weak hindquarters were mentioned by observers as the principal results of the breed's "degeneration" in the Pantanal. It was also an aggressive animal, and was known to attack even riders on horseback, a temperament hardly ideal for the raising of cattle on a commercial scale ${ }^{28}$.

In the cerrado and campo limpo, the traditional breed names included caracu, franqueiro, and chino. Like correntino cattle, the franqueiro had exceptionally long horns (when removed, each horn was said to be capable of holding as much as 5 to 6 liters of liquid), and a powerful head and strong front quarters, making the breed well suited as draft oxen. It also sported a highly-prized thick hide. But it had a low meat-to-bone ratio and was a poor reproducer, lowering its value in the national market, especially with the increase in the demand for beef during the First World War ${ }^{29}$.

More widespread and useful was the chino, during the period an animal found not only in Mato Grosso, but in Minas Gerais, Goiás and São Paulo. The chino had short horns and was prone to skittishness if not kept near humans, but was docile once accustomed to their presence. And they were hardy enough to survive the long drives to Minas and São Paulo. The major drawbacks to the breed, however, were its relatively small size, with correspondingly low amounts of meat, and its tendency to become commercially less desirable if subsequent generations were not regularly crossbred with more corpulent and docile animals ${ }^{30}$.

This brief examination of the original breeds of cattle in Mato Grosso reveals the state of the local ranching industry in producing cattle that could be marketed at a profit outside of the state. There were regular calls for improvement of breeds

\footnotetext{
${ }^{28}$ LISBOA, Miguel Arrojado Ribeiro. Op. cit., p. 136-137; RONDON, J. Licídio N. Tipos e aspectos do Pantanal. São Paulo: n.p., 1972, p. 58-59: COTRIM, Eduardo. Op.cit., , p. 136-145; ANDRADE, Dolor F. Op. cit., p. 7; DOMINGUES, Otavio, ABREU, Jorge de. Op. cit., p. 17. ${ }^{29}$ ENDLICH, Rodolpho. Op. cit., n. 3, 1902, \#12, p. 742-744; LISBOA, Miguel Arrojado Lisboa. Op. cit., p. 137-139; COTRIM, Eduardo. Op. cit, p. 136-145.

${ }^{30}$ ENDLICH, Rodolpho. Op. cit., n. 3, 1902, \# 12, p.745-746; LISBOA, Miguel Arrojado Lisboa. Op. cit., p. 140; COTRIM, Rodolpho. Op. cit., p. 136-145; CARVALHO, Ricardo Ernesto Ferreira de. Industria pastoril: promptuário de noções geraes e especias de zootecnia. São Paulo: n. p., 1906, p. $159-160$.
} 
over the decades, particularly directed to the importation of European breeds, again deferring to the phenomenal success of cattle raising in Argentina as the criterion worthy of emulation. Government officials, ranchers, veterinarians, even state presidents, all suggested the introduction of breeds like Hereford, Durham, Polled Angus, etc. to improve local stock. There was a clear belief that the Mato Grosso ranching industry required more modern methods if it was to provide greater wealth for ranchers and the state, but there was less understanding of the character of tropical ranching and the suitability of certain breeds to the region ${ }^{31}$.

\section{Controversy and Accommodation - Foreign Breed Introductions}

In Mato Grosso, the first serious effort to import European breeds was by Brazil Land, which introduced purebred Durham/Shorthorn just before World War I. This experiment was followed by several other ranchers in the region, particularly foreign interests. Several foreign companies had invested in Mato Grosso just before or during the war, including French, British and Argentine interests. All sought to "improve" the "scrawny" cattle of the region with European breeds. Indeed, the introduction of animals that had proven their efficacy in North America, Europe, Argentina, or even Rio Grande do Sul, was seen as inevitable, and the only obstacle was the "backwoods" rancher who allegedly was only content with the status quo. These experiments, however, met with decidedly mixed success ${ }^{32}$.

\footnotetext{
${ }^{31}$ Relatório do vice-presidente Dr. José Joaquim Ramos Ferreira devia apresentar à Assembléa Legislativa Provincial de Matto Grosso, 2a Sessão da 26a legislatura de Setembro de 1887. Cuiabá: n. p. 1887, n. p.; LISBOA, Miguel Arrojado Lisboa. Op. cit., p. 140; TRAVASSOS, J. Carlos. Op. cit.,p. 35-36; RUFFIER, Fernand. Dos meios de melhorar as raças nacionaes. Primeira Conferencia Nacional de Pecuária. These n. 12. Rio de Janeiro: n. p., 1917, p. 58-59, 65-66.

${ }^{32}$ CORRÊA FILHO, Virgilio. Op. cit., p. 48-50; GAULD, Charles A. The Last Titan. Percival Farquhar, American Entrepreneur in Latin America. Stanford: Institute of Hispanic American and Luso-Brazilian Studies, 1964, p. 209, 220. Letter from T. G. Chittenden, General Manager of "Brazil Land, Cattle and Packing Company", through the British Embassy in Rio de Janeiro, to the President to Brazil,, São Paulo, August 9, 1920. Documentos Avulsos, lata 1920-C, APMT; BENEVIDES, Cezar, LEONZO, Nanci. Miranda Estância: Ingleses, peões e caçadores no Pantanal mato-grossense. Rio de Janeiro: Fund. Getúlio Vargas, 1999, p. 28-30.
} 
There was considerable enthusiasm for these introductions, as reports from managers proudly argued that soon the exceptional future of ranching in Mato Grosso could be met by breeding Shorthorn and Hereford with local Creole cattle. Brazil Land contracted cattle expert Murdo Mackenzie in 1911, and soon after arriving in Brazil Mackenzie sought to "improve" the stock of the ranches by importing these breeds from abroad. Drawing on his experience as manager of Matador Ranch operations in Texas and as president of the U.S. Stockmen's Association, the transplanted Scot imported 900 purebred Shorthorn and Hereford animals from the U.S. to begin a breeding program that would serve the reported 230,000 local head on the company's several ranches. The operations were supported by public policy beginning in 1911, which included Federal government incentives and subsidies to ranchers who sought to rationalize their cattle raising through scientific breeding programs and importations of "improved" breeds, equipment, and methods in common use in other cattle-raising nations, especially the United States and Argentina. Brazil Land's model was clearly the U.S. cattle industry, which had experienced dramatic changes in its production over the previous decades, particularly replacement of the Longhorn with European breeds like the Shorthorn and Hereford ${ }^{33}$.

The same situation was found in another ranch supported by British capital. In their study of Miranda Estância, Cezar Benevides and Nanci Leonzo argue that foreign concerns were in the forefront of ranching modernization in the state ${ }^{34}$. The priorities were much the same as most other foreign operations: improved breeds of cattle, division of property through fencing, building of corrals and cattle chutes and dips, establishment of water tanks and windmills, and seeding of pastures with introduced grasses considered to be of better quality for the cattle. The British investors even installed telephones to link ranch headquarters with line camps (retiros) scattered across the ranch ${ }^{35}$.

${ }^{33}$ GAULD, Charles. Op. cit., p. 220; HANSEN, Simon G. "The Farquhar Syndicate in South America". The Hispanic American Historical Review, 17:3, august 1937, p. 319-320; DOWNES, Earl Richard. The Seeds of Influence: Brazil's 'Essentially Agricultural' Old Republic and the United States, 1910-1930. PhD. Dissertation, The University of Texas, Austin, 1986, p. 94-97.

${ }^{34}$ BENDEVIDES, Cezar, LEONZO, Nanci. Op. cit., p. ix, 26.

${ }^{35}$ Idem, p. 36-37. 
However, these "experiments" did not generate the results expected. For Brazil Land, experience was learned early. Soon after the importation of breeder animals from Texas severe weather hit the company's operations hard in southeastern Mato Grosso. Hard frosts in the winters of 1917 and 1918 destroyed newly-sown alfalfa pastures, causing considerable mortality among imported stock and prompting the company to halt further importations and to concentrate on zebu-crioulo crosses. It was apparent early that the purebreds were hardly suited to the Mato Grosso environment, unaccustomed as they were to the local forage, and they suffered from the intense sun, insect plagues, and the like. And with the exception of breeder animals, success even with crossbreds was limited. The heat, ticks, foot-and-mouth disease, warble fly (berne), and a number of minor diseases took their toll. The animals gained weight slowly, often aborted, suffered berne fly burrowing in their hides, and were victims of the most common cattle disease in the region, black leg (symptomatic carbuncle - manqueira). This latter was relatively benign to crioulo cattle, but found new hosts in the imports and crosses and became a constant worry for ranchers who were trying to improve their herds. Medicines and dipping were applied, but at this early stage little was known about some of the diseases, and vaccines were rudimentary and expensive, or in the case of foot-and-mouth, not yet developed. This was particularly noticeable in the winter of 1918 , when the disease spread into several Brazil Land ranches, requiring vigilant oversight and application of prophylactics, especially for purebreds, while crioulos and zebu seemed to shake off the affliction. Well into the 1930s, purebred animals were through quarantine and dipping (though this had no effect on foot-and-mouth), and the company frequently took the extraordinary step of posting a guard to prevent outside dogs and other animals from entering the property. Foot-and-mouth became endemic to the region, but in the early years had a much more serious impact on purebred cattle than crioulo ${ }^{36}$.

\footnotetext{
${ }^{36}$ BERTELLI, Antonio de Pádua. O paraíso das espécies vivas: Pantanal de Mato Grosso. São Paulo: Cerifa, 1984, p. 225-226; Cables from T. G. Chittenden to W. C. Forbes and C. E. Perkins, July 6, September 14, October 16, Vol.. 11,William Cameron Forbes Collection, Baker Library, Harvard Business School. [hereafter WCFC-BL-HBS]; Letter from John Mackenzie to Don F. Biggs, August 9, 1937, Vol. 22, WCFC-BL-HBS. Foot-and-Mouth, which as a viral disease is not spread by ticks like Texas Fever, is still endemic to parts of Brazil, Argentina, and Paraguay, despite plans for the region to be disease-free by 2009. Serious outbreaks occurred in Argentina and Brazil (including Mato Grosso do Sul) in 2000 and 2006, bringing into question the likelihood of the region realizing such plans.
} 
It may have been that the animals did not receive the care they required, considering their relatively delicate nature, but the experience convinced Brazil Land of the need to raise more rustic breeds, and other ranchers of the inadvisability of importing more European animals. The inability of the railroad to provide regular livestock transport also contributed to this decision. The solution chosen by Brazil Land, and already followed by a number of ranchers in the state, was to turn to another exotic breed - zebu and zebu crosses. Even Murdo Mackenzie eventually saw zebu as valuable, if simply as a variation on crioulo and as the base of a potential breeding stock with Hereford. While he stuck to the certainty that breeding animals with stock from Texas would produce better animals for the future, he accepted the immediate practical value of $\mathrm{zebu}^{37}$.

\section{The "Asiatic Plague" - Zebu}

Stimulated by innovative ranchers in the western part of the state of Minas Gerais bordering Mato Grosso, the Indian humped breed, the Zebu, began to be introduced onto their ranches as early as the 1870s. Zebu cattle are not only a different breed from what was common in Brazil and most of the western world, but were sometimes classified as another species. The European-origin animal is generally classified as Bos taurus taurus, and is acknowledged to have developed independently in southern Europe, although its initial origin was probably west Asia or Africa. The Indian subcontinent beast, Bos taurus indicus or Bos indicus, also developed separately, again likely from the same obscure origins ${ }^{38}$.

\footnotetext{
${ }^{37}$ BARROS, Paulo de Moraes. O sul de Matto Grosso e a Pecuária. 1922, p. 12, 17-21; MATTO GROSSO. Município de Campo-Grande. Relatório do anno de 1922, Apresentado á Câmara Municipal pelo Intendente Geral Dr. Arlindo de Andrade Gomes. São Paulo: Comp. Melhoramentos, n.d., p. 15-16- Various reports from T. G. Chittenden to Murdo Mackenzie, 1917-1919, NB 8-12, WCFC-BL-HBS, Murdo Mackenzie, "Brazil as a Market for Purebred Cattle", The Breeder's Gazette. Chicago. Vol. 86, n. 26, December 25, 1919, p. 1364-1365, 1488.

${ }^{38}$ SANTIAGO, Alberto Alves. O zebu na Índia, no Brasil e no mundo. Campinas, SP: Instituto Campineiro de Ensino Agrícola, 1985, p. 8, 12-15; NORRIS, William, ed. The Heritage Illustrated Dictionary of the English Language. New York: Heritage Publishing, 1975, p. 1488; LOPES, Maria Antonio Borges, REZENDE, Eliane M. Marquez. Op. cit., p. 17-19, 22-23. For the sake of simplicity of language occasionally zebu will be referred to as a "breed", as it often is even today, although this is scientifically incorret.
} 
Casual experiments in the countryside of Rio de Janeiro and unpredictable climatic conditions in Minas Gerais led some ranchers to seek animals bettersuited to their region than their sometimes desultory experience with Europeanorigin breeds. These ranchers soon sought to import animals directly from India, a decision that revolutionized Brazilian tropical ranching and became the focus of a sometimes acerbic debate over the course of the first decades of the twentieth century that illustrates the concept introduced here of the "ethnocentric steer" 39 .

In Mato Grosso, zebu entered through the cattle trails between the state and neighboring Minas Gerais. It was soon adopted by a number of ranchers, despite official promotion of European breeds. Indeed, zebu dominated on the ranches of Brazil Land in the neighboring states of Paraná and Minas Gerais by the end of W.W. I, and was soon adopted in ranches closest to Campo Grande in Mato Grosso. By 1918, the company was buying high grade zebu breeders for several of its ranches, with the apparent intention of expanding the quality of its crioulo herds. This was the response of a company that from the start had invested considerable money and time into Shorthorn and Hereford breeders. These breeds were not abandoned, but the reality of market and local conditions fashioned a practical shift in priorities by the managers. Consistently, their reports and letters expressed the view that if only Brazil could "improve" its stock with European breeds the nation's cattle industry had a fabulous future. However, by the 1940s when Brazil Land properties had passed out of foreign hands and into possession of Brazilian ranchers, the bulk of company cattle were zebu-creole cross, a practice that was built upon by the new owners. Zebu had some years yet to establish its complete dominance in Brazilian ranching, but it was clearly on the way and the foreign concern's experiments with European breeds in semi-tropical and tropical ranching had convinced no one. Miranda Estância went through a similar experience $^{40}$.

\footnotetext{
${ }^{39}$ SANTIAGO, Alberto Alves. Op. cit., p. 169-171.

${ }^{40}$ Letter from Ray Vivian to Belle Burns, Fazenda Paracatú, Minas Gerais, December 22, 1914. Box 13 - Brazil, Land, Cattle, and Packing Company, Southwest Collection/Special Collections Library, Texas Tech University, Lubbock Texas [hereafter MLCCR-SWC/SCL-TTU]; BARROS, Paulo de Moraes. Op. cit., p. 23-25; RUFFIER, Fernand. Guerra ao Zebú, um pouco de agua fria... Castro: n. p., 1919, p..10-12; T. G. Chittenden Report, June 4, 1918, NB 11, WCFC-BL-HBS.
} 
In the beginning, Miranda Estância was forced to rely primarily on its stock of local creole cattle, though early on attempts were made to introduce Red Polled and Hereford to the property. However, these met with considerable difficulties and did not prosper at all, suffering similar obstacles as Brazil Land. While it was still believed that these and other European breeds were the key to the future of the region's cattle sector, the ranch could not create conditions for the animals to prosper, "whether due to bad administration or a lack of a good work method," according to M. Labatut, the manager of a neighboring French-owned operation ${ }^{41}$. Still, it took some time for the ranch's management to accept that in the rudimentary conditions of Mato Grosso temperate climate cattle did not do well. With the gradual acceptance of zebu across tropical and semi-tropical Brazil, however, this breed eventually entered Miranda Estância in the mid-1920s, over ten years after the operation began. Zebu, especially Nellore, soon became the breeders for the ranch, though well into the 1940s they were still fewer than pantaneiros and crossbreeds $^{42}$.

At the same time, pressures from these importations of Hereford and Durham, and the introduction of zebu in Minas Gerais, caused Brazilian breeders in São Paulo to promote yet another breed - the caracu. The caracu in fact, became the focus of an intense nationalist debate after 1900, as it was touted as the only truly "national" breed in the country, and should be protected from the "invasions" of exotics, above all zebu. Allegedly a direct descendent of the original Portuguese cattle, or animals brought to the northeast of the country during the Dutch occupation of the seventeenth century, the promoters of caracu praised the animal for its rusticity, mild temperament, and quality (if not quantity) of meat. According to Carlos Travassos, the breed had become virtually extinct by the end of the nineteenth century. However, it was given a new lease on life thanks to a campaign by a number of cattlemen from São Paulo, who believed in the improvement of caracu as the most logical choice for Brazilian breeders due to its long history in the country. Veterinarian Dr. Eduardo Cotrim suggested the establishment of zoo technical posts to improve the breed, and to develop a breeding program that could supply the

\footnotetext{
${ }^{41}$ A Fazenda Francesa, seus recursos e sua exploração. Relatório de monsieur Labatut. Guaicurus, Mato Grosso, 4.10.1920. [quoted in BENEVIDES, Cezar, LEONZO, Nanci. Op. cit., p. 37].

${ }^{42}$ BENEVIDES, Cezar, LEONZO, Nanci. Op. cit., p. 67.
} 
national market. This advice was followed, and in 1916 a caracu stud book was created. Breeding was done in the São Paulo state agricultural research station at Campinas, and improvement over the years in the breed's fertility, weight gain, and docility was cited as proof that a Brazilian breed could be developed ${ }^{43}$.

However, caracu did not show good meat-to-bone ratios, even in crosses with European breeds, while it was unreliable in extreme weather conditions and ultimately best-suited for draft purposes ${ }^{44}$. Yet promotion of the caracu tied into a sometimes nasty debate over the efficacy of zebu to Brazilian cattle production that took on many of the characteristics of racial diatribes reminiscent of discussions of human value in nineteenth century Latin America. The debate was heated and inflammatory, and the first salvo was launched in 1904 by Dr. Luis Pereira Barreto, a respected São Paulo agricultural scientist and physician. While Pereira Barreto acknowledged that the first generation of zebu was "truly splendid," he didn't mince words about succeeding generations:

...the second is already much inferior; the third very bad; the fourth is a juvenile goat herd; the fifth a herd of long-eared hares; the sixth, finally is of debilitated rats, wretched, infertile....Zebu meat has the rankness of capybara; cows don't have enough milk to raise their young; males and females are wild beasts ${ }^{45}$.

Such strong rhetoric touched off a bitter controversy that pitted supporters of Pereira Barreto, most of whom were from São Paulo, against defenders of the zebu, who were, not surprisingly, largely from Minas. The debate went on for decades, and was not fully resolved in the minds of some participants even into the 1940s.

\footnotetext{
${ }^{43}$ RUFFIER, Fernand. Dos meios..., op. cit., p. 3, 53-57; TRAVASSOS, J. Carlos. Op. cit., p. 34; COTRIM, Eduardo A. Torres. "Contribuição para o estudo das vantagens ou desvantagens da introducção do sangue do gado Zebú nas nossas manadas”. Inauerito sobre o gado zebu. Rio de Janeiro: Sociedade Nacional de Agricultura, 1907, p. 87-89; CORRÊA, Arary Prudente. "A raça caracú e a pecuaria do Brasil central”. Gado Caracu. Orgão da Associação Herd Book Caracú. São Paulo, n. 2, Janeiro 1937, p. 9-10.

${ }^{44}$ CAVALCANTI, Manuel Paulino. Raças de carne. Rio de Janeiro: Ministério da Agricultura, Industria e Commercio, 1938, p. 33-36; COTRIM, Eduardo A. Torres. Contribuição... op. cit., p. 87-89.

${ }^{45}$ LOPES, Maria Antonia Borges, REZENDE, Eliane M. Marques de. Op. cit., p.34. Pereira Barreto was also a planter and public health expert in São Paulo. He was a major figure in the movement for agricultural improvement in the state and was at one time Secretary of Agriculture. His contribution to São Paulo's economic development was recognized by giving his name to a town.
} 
Equally harsh words were expressed by Dr. Assis Brasil, a renowned ranching specialist from Rio Grande do Sul. Assis Brasil admitted no positive characteristics for the zebu whatsoever, calling it the "Asiatic plague" and characterizing its champions as having succumbed to "collective hysteria." Less strident in his criticism was the respected Eduardo Cotrim, whose experience with cattle was extensive, but largely confined to Rio Grande do Sul and Rio de Janeiro. In his highly-regarded manual on cattle raising published in 1913, Cotrim opined that the immense popularity of this "hindu idol" in recent years had produced a painful experience for Brazilian ranchers, who did not understand that in the course of countless centuries in India the zebu had "proven" it was incapable of improvement. He had argued earlier that the zebu was good only for traction, although somewhat hard to handle, but that as times changed the need for traction animals was rapidly diminishing. He disparaged the animal's meat, saying that it was of secondary quality because the breed did not adapt well to "luxurious" pasture areas. And he warned that zebu milk production was exceptionally low, calf care by cows minimal, and the procreation rate well below that of the more traditional breeds, like caracu. The addition of Cotrim's voice to the discussion gave considerable legitimacy to the anti-zebu lobby ${ }^{46}$.

But there were several defenders of zebu. Carlos Fortes, a Mineiro animal expert, noted in 1903 that cattle breeds should be chosen depending on the location with zebu the best selection for remote regions, either as purebreds or as scientificallycontrolled crosses. His point was that the animal's rusticity and productivity under less than ideal conditions made it a natural choice for ranchers in regions like western Minas, Goiás and Mato Grosso. Others, including some federal government technicians, argued that the zebu was ideally adapted to the tropical climate of Brazil, produced better than its detractors made out, and was especially resistant to diseases that frequently incapacitated European breeds. This was particularly important, given that similar arguments were made for local breeds as well ${ }^{47}$.

\footnotetext{
${ }^{46}$ LISBOA, Miguel Arrojado Ribeiro. Op. cit., p. 154; COTRIM, Eduardo A. Torres. A Fazenda..., op. cit., p. 135; COTRIM, Eduardo A, Torres. Contribuição..., op. cit., p. 71-92.

${ }^{47}$ FORTES, Carlos Pereira de Sá. Industria pastoril. Relatório apresentado à commissão fundamental do Congresso Agrícola, Commercial e Industrial de Minas. Belo Horizonte: n. p., 1903, p. 4-7, 11-12, 18-24; LOPES, Maria Antonia Borges, REZENDE, Eliane M. Márquez de. Op. cit., p. 35-36.
} 
An important ally for the zebu lobby was Carlos Travassos, a powerful member of the National Agricultural Society in Rio. In a study of zebu in Brazil and in India Travassos noticed that while zebu weight was markedly less than that of European breeds in ideal conditions, the Indian animal was best adapted to the local climate in a number of ways: longer ears to sweep away flies; usually light hair color, reflecting sun; darker skin pigmentation making resistance to ultraviolet light much greater; resistance to tropical parasites; less sweating, therefore greater absorption of heat by droplets. Travassos relied heavily on work done by English scientist Robert Wallace in India in the 1870s. Significantly Wallace, who made the first scientific study of zebu, also recounted failed attempts to import English breeds into the British colony in order to "improve" local cattle. Wallace and later scientists concluded that European cattle were unsuited to the tropics, and that to improve local zebu, breeder stations and veterinary schools should be established. Travassos argued that the same should be done in Brazil. He lamented a lack of vision among Brazilian legislators and scientists, pointing out that several other Latin American nations had veterinary schools, India had several, and even distant Siam (Thailand) was so equipped ${ }^{48}$.

Nevertheless, many scientists and ranchers rejected Travassos' work, and the debate refused to die, particularly due to the untiring lobbying of Pereira Barreto and other Paulistas, obsessed as they were with the political agenda of promoting a "national" breed centered in São Paulo. In Mato Grosso, Pereira Barreto's columns in the prestigious São Paulo daily O Estado de São Paulo sometimes influenced local ranchers, as witnessed by one Pantanal stockman who refused to introduce zebu to his property for decades ${ }^{49}$. However, zebu continued to grow in importance in the state, particularly in cross breeding with local breeds like the franqueiro and chino. In some cases, where ranchers provided little care, these animals became so wild they posed a risk to humans and other, more docile cattle, forcing owners to destroy them. However, zebu was the breed of choice by the end of the First World War, especially because of its ability to withstand the long and arduous cattle drives to São Paulo. Extensive exports of zebu meat to warring Europe also convinced many doubters of the product's marketability and its place in the national economy.

48 TRAVASSOS, J. Carlos. Monographias agrícolas. Rio de Janeiro: n. p., 1903, p. 257-296, 321323, 330-332.

${ }^{49}$ Interview with Dr. Renato Alves Ribeiro, Campo Grande, May 29, 1990. 
Zebu was on the way to predominating in Campo Grande and the Vacaria, and ranchers in the Pantanal, who were much slower in adopting the breed, first began to import zebu breeders during and after the war. The controversy died down at this time, and even Eduardo Cotrim accepted zebu for central Brazil's ranching industry, although he stressed the need for selection and breeding care ${ }^{50}$.

But the debate did not go away, and in 1918 and 1921 the anti-zebu lobby received a tremendous boost from external sources, influences that would keep the issue prominent for most of the 1920s. At issue was the quality of zebu meat. Zebu detractors argued that the breed had less fat than European cattle and was thus unpalatable to the European consumer (above all British), compared to beef exported by Argentina. This was part of the argument used by the London Board of Trade in 1918 when it banned the import of Brazilian beef. A furor developed over the ban, and the more extremist anti-zebu lobby called for an end to the import of zebu breeder stock and the slaughter of all zebu, with concentration on the raising of only European breeds, above all English. This approach was countered by Ruffier, who responded by arguing that Brazilian meat had been rejected due to poor preparation by the slaughterhouses infected by the feverish demand of the war. Scrawny animals recently arrived after grueling three-month drives were immediately slaughtered and often the meat was frozen too rapidly. As a result, the meat reaching England suffered from freezer burn and was tough and discolored. In addition, Ruffier was convinced that politics played a role, as the policy of exclusion protected British cattle interests in Argentina and Britain. He pointed out that, along with the ban, the Board of Trade had recommended that Brazil import purebred English bulls to rejuvenate its herds:

[T]o neutralize those defects [of zebu] it is necessary to import purebred English cattle, like Hereford, Devon, Shorthorn, etc....England is the country best equipped to provide Brazil with the necessary breeds ${ }^{51}$.

\footnotetext{
${ }^{50}$ CORRÊA FILHO, Virgilio. Op. cit., p. 44-46; “A creação em Matto Grosso”. Brasil Agrícola. Rio de Janeiro, n. 1, Dec. 1916, p. 362-363; RONDON, General Candido Mariano da Silva. MattoGrosso - o que elle nos offerece e o que ele espera de nós. Conferência realizada a 31 de Julho de 1920, pelo Exmo. Snr ..., perante a Sociedade Rural Brasileira na cidade de S. Paulo. São Paulo: n. p., 1920; BARROS, José de. Lembranças para os meus filhos e descendentes. São Paulo: n. p., 1987, p. 63; “Congresso de Pecuária”. Correio Paulistano. São Paulo, Sept. 23, 1916, p. 3-4.

${ }^{51}$ RUFFIER, Fernand. Guerra..., op. cit., p. 7-10.
} 
Although Ruffier exhibited some clear distrust of British intentions, there is no masking an obvious British attempt to promote the interests of that nation's breeders. It was not the first time London had used a seemingly minor issue to manipulate the market in its favor ${ }^{52}$.

While part of the Brazilian agricultural sector went into a frenzy, others did not take the ban too seriously. After all, there was still a market in the rest of Europe, especially France and Italy. Many officials and cattle raisers had come to the conclusion that zebu was indeed the beast of the future, and breeder imports from India were resumed in 1919. But this importation inserted an element into the debate that was totally unexpected - an outbreak of rinderpest that hit São Paulo city and environs in $1921^{53}$.

This devastating cattle disease was traced to a lot of recently-imported zebu, which had either picked it up on a stopover in a Belgian port, where it was also detected, or had passed it on there. The Brazilian government immediately prohibited further imports of zebu, and neighboring countries and some European nations banned the entry of Brazilian animals and meat. The outbreak was controlled by the Brazilian authorities, who not only destroyed cattle, but also dogs and ravens in the vicinity, and who disinfected rail cars, stock and packing areas, and temporarily closed the slaughterhouses. As a result, the plague did not spread beyond São Paulo city, although there was considerably concern in other regions of the country, including Mato Grosso, and the cattle trade in central Brazil was disrupted for several months as a result. As might be expected, the issue was exploited by the anti-zebu lobby, which argued that not only were zebu rachitic and degenerate, but were also repositories of a disease that could decimate the national herd ${ }^{54}$.

The short term impact was to depress further an already stagnant postwar ranching sector. There were only two importations of breeders from India during

\footnotetext{
${ }^{52}$ Idem, p. 18-28; DOMINGUES, Octávio. O zebu, sua reprodução e multiplicação dirigida. São Paulo: Nobel, 1971, p. 40, 43.

${ }^{53}$ SANTIAGO, Alberto Alves. Op. cit., p. 143-145, 169-170.

${ }^{54}$ United States. Department of Agriculture. Trade Report N. 173, by W. L. Schurs, U. S. Commercial Attaché, Rio de Janeiro, April 12, 1921, "Cattle Plague in State of São Paulo", and Trade Report n. 292, by Bernarde H. Noll, U. S. Trade Commissioner, Rio de Janeiro, January 7, 1922, "Imports of Zebu Cattle Suspended", Record Group 166- Records of the Foreigh Agricultural Service, Narrative Agricultural Reports, 1904-54. Brazil, entry 5, box 64, USNA.
} 
the period, in 1921 and 1930. Meat exports picked up by 1923, however, and the impressive expansion of the 1920s served to encourage official action. In 1926, the Mato Grosso government offered a subsidy to ranchers who introduced purebred European animals and "bred up" their herds to no less than $15 \%$ pure European. Yet zebu continued to dominate, partly aided by improved treatment of cattle and meat by the frigoríficos and by an unexpected source, a representative of the British Ministry of Agriculture who visited the country in the late 1920s. This official, John Lamb Frood, visited Minas Gerais and was impressed by the quality of zebu found there. He suggested that greater crossbreeding with breeds like Hereford or Polled Angus might be beneficial, but assured Brazilian ranchers that he was returning to England convinced of the value of zebu in providing beef for the European market. He also judged that Brazilian slaughterhouses were processing the product better than those in Argentina ${ }^{55}$.

Frood's opinion was echoed by Sir Edmund Vestey, head of the British conglomerate that controlled a number of Brazil's frigoríficos. Vestey visited Brazil in 1927 and confirmed Ruffier's earlier assessment that Brazil had lost clients for its meat in the postwar period due to the treatment of the cattle, not the breed. He too suggested crossing with European breeds, but believed that the zebu was the best animal for the country, particularly in interior regions like Mato Grosso. He also urged completion of the bridge over the Paraná River, and rail freight rates based on carload and not per head. These visits legitimized the zebu as a viable animal in the production of beef for export, albeit with the caveat that more scientific breeding methods be employed ${ }^{56}$.

The result was that between 1921 and the 1940s, zebu came to dominate as the major breed in Central Brazil. Most opposition had been overcome by the 1940s, and the bulk of ranchers, buyers and veterinarians, even in São Paulo, became

${ }^{55}$ CAMERON, C. R. "Matto Grosso and its Finances", Consular Report, 24 December, 1927, U. S. Departament of State, Division of Latin American, n. 832.51M43/2, Reports of U. S. Consuls in Brazil, 1910-29, microfilm M-519, roll 27, U. S. National Archives , Washington, D. C.; SANTIAGO, Alberto Alves. Op. cit., p. 169-170; "Propaganda de Matto Grosso e a zona Noroeste", Almanaque Illustrado. Tres Lagoas, Mato Grosso, v. 2, 1929, p. 243-246.

56 “Uma opinião sobre o gado zebu” Gazeta deCommercio. Tres Lagoas, n. 7, July 27, 1927, p. 4. Vestey had three packing houses in Brazil, at Barretos, Santos in São Paulo and Mendes near Rio de Janeiro. 
believers. In Mato Grosso, zebu were the main breed by the late 1930s, particularly in Campo Grande and the Vacaria. Dolor Andrade explained that the reasons were simple: hardiness; precocity of calves; resistance to parasites; and ability to swim, essential in the fording of rivers and streams during drives. The capacity to endure the long drives to market with minimal deleterious effects and to regain weight quickly was central in the decisions of Mato Grosso ranchers to opt for zebu, despite the controversy surrounding its value. In fact, by 1940 Mato Grosso reportedly had a higher proportion of zebu in its herd than any other region of Brazil, including Minas and Goiás. Most of the zebu were not purebred, however, as they were the products of both deliberate and uncontrolled crosses with local animals. This led to the development of a distinctly Brazilian zebu breed that reflected the rather superficial perceptions of the quality of breeds held by cattlemen in Brazil at the time ${ }^{57}$.

The majority of purebred zebu imported from India were Nelore (Ongole in India), Gir, and Guzerá (Kankrej in India). Why these three breeds were chosen is not entirely clear but seems to have had something to do with breeding in India, their dominance in that country, and their ability to satisfy the fundamental criterion of Brazilian buyers - durability, docility and adaptability to a variety of purposes. But Brazilian inexperience with Indian cattle led to the choice of animals on the basis of external features, particularly color, extent of dewlap, and, in later years, the length of ears. Indeed, at the height of Brazilian purchases, Indian cattle traders jocularly referred to the Brazilians as "buyers of cattle ears." Such irrelevant criteria were to mark the marketability of animals throughout the 1920 s and into the 1930s, and became part of a debate over the development of a distinctly Brazilian zebu breed, the Indubrasil ${ }^{58}$.

Up to the First World War, purebred animals were crossed with local animals, but with minimal control over breeding. This fueled the zebu controversy and,

\footnotetext{
${ }^{57}$ ANDRADE, Dolor F. Op. cit., p. 7-8; LEITE, Gervasio. O gado na economia matogrossense. Cuiabá: Esc. Prof.. Salesianas, 1942, p. 9-11; OLIVEIRA, Antonio Carlos de. Economia pecuária do Brasil Central: bovinos. São Paulo: Departamento Estadual de Estatística de São Paulo, 1941, p. 184-185.

${ }^{58}$ MENEZES, Durval Garcia de. O Indubrasil: conferencia pronunciada em 2 de Maio de 1937 no recinto da 3a Exposição Agro-pecuaria de Uberaba, em homenagem à "Sociedade Rural do Triangulo Mineiro". Rio de Janeiro:Sociedade Rural do Triangulo Mineiro, 1937, p. 8; SANTIAGO, Alberto Alves. Op. cit., pp. 72-72, 81, 86, 468.
} 
coupled with continued high costs of importing, influenced the decision by a number of Mineiro ranchers to develop a distinctly Brazilian breed. Independent of any government assistance, the Indubrasil developed as a response to the wartime market, and became the dominant zebu by the 1930s. It was mainly a cross between Gir and Guzerá, although other zebu stock was not entirely absent. But it was a pure zebu breed, with no input from Bos taurus taurus. The creators of the Indubrasil succeeded in obtaining a much greater amount of meat per animal than provided by zebu crossed with European breeds, and by 1930 it was touted as the savior of the Brazilian cattle industry ${ }^{59}$.

The fact that Indubrasil had long ears came to be the measure by which animals often were judged for purity, largely because most Brazilian ranchers had limited experience with breed selection and thus relied on the animal's unusual external features to determine purchase decisions, as had buyers in India. In many cases, breeders with the longest ears fetched the highest prices on the open market. Ranchers then believed they were breeding with purebred stock, when in fact the animals may have carried no more than three-quarters or seventh-eighths zebu genes. This led to inadvertent crossbreeding that eventually caused animals to develop that did not produce to expectations, further fueling the debate over zebu quality $^{60}$.

Thanks to this boom. by the late 1930s it became clear that the stocks of purebred Indian cattle had become precariously low in Brazil. This prompted the federal government to stimulate the breeding of pure blooded stock and to guarantee genealogical lines through herd and stud books. Between 1934 and the early 1940s, federally-funded experimental ranches were set up in Minas Gerais and São Paulo. The 1930s saw the development of a national Genealogical Registry Service through the Rome Agricultural Conference of 1936, and zebu registry was authorized two years later. These measures were instrumental in guaranteeing zebu a permanent place in Brazilian ranching circles, and in preserving the small numbers of purebred stock still in existence. They also ensured a place for

\footnotetext{
${ }^{59}$ MENEZES, Durval Garcia de. Op.cit., p. 16-19; SANTIAGO, Alberto Alves. O Nelore: origem, formação e evolução do rebanho. São Paulo: n. p., 1958, p. 125-131.

${ }^{60}$ MENEZES, Durval Garcia. “O Zebu - Riqueza Paulista”, O Zebu. Uberaba, n. 1, August 1940, p. 15 .
} 
Indubrasil, which was officially recognized as a distinct breed in 1936, although its prominent place in Brazilian selective breeding did not continue ${ }^{61}$.

From 1940 until the 1950s, Indubrasil was the dominant breed among registered zebu purebreds, although there was some concern over the extent of necessary human intervention, particularly in order to ensure new-born calves would suckle. This contributed to the perceived need to import new blood into the industry, although influenced by the Indubrasil lobby a federal government ban on imports had been in effect since 1930. Official refusal to sanction increased imports led in 1955 to the illegal import from Bolivia of over $100 \mathrm{Gir}$, which were instrumental in guaranteeing the predominance of that breed for a decade. In 1962, legal importation of 318 Nellore injected those genes back into Brazilian herds, as the industry came full circle. No significant imports of zebu were made since, as by that time the industry had become sophisticated enough to engage in its own breeding program, leading to the overwhelming predominance of Nellore in the national herd, with the exception of Rio Grande do Sul. Nellore not only is highly resistant to climatic extremes, particularly under conditions of extensive ranching as in Mato Grosso, but is highly fertile and gains weight easily. The beast's light hair color also plays a role in its adaptability to conditions of hot sun and little shade, common in Brazilian pastures, although it should be pointed out that while pure white is the normal color for Nellore, others do exist. In Brazil, color clearly came to play a part in selection for breeders since most zebu throughout the country today are white Nellore, although unlike the arbitrary prejudice in favor of superficial characteristics seen in the past, the choice of light hair color today has scientific approbation behind it $^{62}$.

It was the advent of zebu that guaranteed Mato Grosso a significant place in the national cattle market, a position already developing before the entry of the breed, but not necessarily assured at that time, especially if European breeds had been the only choice. Mato Grosso ranchers' acceptance of the lead from Minas,

\footnotetext{
${ }^{61}$ Idem, p. 18; LOPES, Maria Antonia Borges, REZENDE, Eliane M. Marquez de. Op. cit., p. 6365; SANTIAGO, Alberto Alves. O zebu..., op. cit., p. 467, 470, 475.

${ }^{62}$ BRAZIL. Ministério da Agricultura. Manual técnico para criação de gado de corte em Mato Grosso. Campo Grande, 1978, p. 2-3; SANTIAGO, Alberto Alves. O zebu..., op. cit., pp. 170-171, $273,354,440$.
} 
and willingness to press on despite arguments to the contrary from São Paulo, ensured they would be in the forefront of the developing technology, as were western Minas and Goiás. In fact, Mato Grosso became one of the most important of the several zebu breeding regions. The state had technologically surpassed São Paulo in cattle breeding, as had Minas. Some observers have suggested that in the long term the anti-zebu campaign was a benefit to Minas and the other zebuproducing states because it permitted them to develop a technology that São Paulo and foreign interests otherwise would have dominated. It was even estimated that the campaign may have cost São Paulo as much as \$100 million in lost sales and production, an assessment if true that reinforces the necessity for caution in introducing exotic breeds before learning the capability of local environmental conditions to support such introductions. As it was, however, the opportunity offered Mato Grosso by zebu was golden, and contributed to placing the state firmly on the road to its present status as a major beef cattle producing region of Brazil, while zebu is he dominant breed throughout tropical Latin America today. Ultimately, the story of zebu in the state and the country affirms that ranching in the tropics was a business very much dependent on untested technology which, with experience still limited, was often, as one wag called it, a jogo de bicho-game of chance $^{63}$.

\section{Conclusion}

In examining the daily routines on most ranches, it becomes clear that the complaints of "backwardness" were often misinformed observations by persons who had little understanding of local conditions. And as time passed and opportunities for sale to outside markets improved, ranchers paid ever increasing attention to their animals. However, they were seldom aided by government administrations inadequately equipped to respond effectively to scientific innovation and economic expansion. Some visitors also accused ranchers of perpetuating their own lack of development. Part of the problem was extensive ranching, engaged in throughout

\footnotetext{
${ }^{63}$ LOPES, Maria Antonia Borges, REZENDE, Eliane M. Márquez de. Op. cit., p. 35-36; LISBOA, Oscar. "Congresso de Pecuária”. Correio Paulistano, Sept 26, 1916, p. 4.
} 
the Americas since the beginning of the colonial era. Until land took on a value other than as a medium for animals to go forth and multiply, ranching relied on the elements for its prosperity. There was certain logic in this, for if climate is sufficiently benign, as it was in most of Mato Grosso, cattle could survive on their own with few inputs from the rancher. There was little competition from other animals, predators (wildcats, especially jaguars) were a nuisance but not a major threat, and there was plenty of forage and even natural salt deposits to sustain significant numbers of animals ${ }^{64}$.

Of course, market demand determines measures taken. The market helped to introduce new thinking and methods into the Mato Grosso ranching regime, which eventually did include participation by state and federal governments. That most perception was guided by experience from abroad should come as no surprise, though this was a major factor in limiting the growth of the Mato Grosso beef industry until the 1940s. The initial obsession of introducing temperate forage and breeder animals because they had been so successful in North America and Argentina was soon proven highly erroneous in tropical settings. As one important rancher pointed out in 1918, "improving" Brazilian herds with European animals was illogical for local conditions. After all, British breeders didn't import zebu to "improve" their herds, nor even use European breeds in India. Instead, he argued, "Do as they do, not as they say" 65 .

Indeed, the Brazilian experience underscores the often unappreciated role of locals in determining what served the region best. They were not as "backward" as accused, but responded to innovation with caution due to the limits of the environments in which they operated. The Mato Grosso ranching sector is a good example of how traditional methods often need to coexist with innovative techniques for some time, as economic growth stimulates the transition from one form of ranching to another. The fact was Brazilian ranchers were "innovative" when

\footnotetext{
${ }^{64}$ MELO E SILVA, José. Fronteiras guaranis. São Paulo: n. p., 1939, p. 146-147; DOMINGUES, Otavio, ABREU, Jorge de. Viagem de estudos à Nhecolandia. Rio de Janeiro: Instituto de Zootecnia, publ. N. 3, dezembro 1949, p. 21.

${ }^{65}$ NEVES, Antonio da Silva. Primeira conferencia nacional de pecuária: origem provável das diversas raças que povoam o território pátrio, alimentação racional, hygiene animal. São Paulo: n. p., 1918, p. 59.
} 
results revealed the efficacy of adopting imported ideas. However, the "improvements" didn't necessarily have to originate in Europe or the United States, but could be "homegrown". The result has been that the "ethnocentric steer," rather than dominating tropical ranching, has instead been absorbed into the sector, becoming more "multicultural" than ranching observers ever could have imagined in the early decades of the twentieth century. 